\title{
Multiple endocrine neoplasia type 2A
}

INSERM

\section{Source}

INSERM. (1999). Orphanet: an online rare disease and orphan drug data base. Multiple endocrine neoplasia type 2A. ORPHA:247698

Multiple endocrine neoplasia 2A (MEN2A) syndrome is a form of MEN2 (see this term) characterized by medullary thyroid carcinoma (MTC; see this term) in combination with pheochromocytoma (see this term) and primary mild hyperparathyroidism resulting from hyperplasia or adenoma of the parathyroid cells. 